\title{
THE SOUTHERN RETREAT, THOMAS HODGKIN, AND ACHILLE-LOUIS FOVILLE
}

by

\section{CHARLES L. CHERRY*}

DOCUMENTS AT THE Library of the Religious Society of Friends in London ${ }^{1}$ reveal an attempt in 1839 by prominent Quakers to establish "The Southern Retreat" as a counterpart to the already famous Tuke-inspired York Retreat. Though unsuccessful, the effort is interesting in several respects, not the least being the close involvement of Thomas Hodgkin and his relationship with Achille-Louis Foville.

Spurred by the failure of Friends to gain admittance to York Asylum to visit Hannah Mills, a forty-two-year-old Quaker widow who eventually died in that institution on 29 April 1790, William Tuke in 1792 proposed the establishment of an asylum for Quaker insane, and on 16 May 1796 he opened York Retreat. The Retreat had as its philosophical foundations a commingled sense of religious exclusivity and a humanitarian concern for minds closed to the Inner Light; also implicit was an empirical awareness that the "beat and bleed" therapies conventional in many institutions were not only cruel but ineffectual. The success of its policy of moral management and the increasing reputation of the Retreat in the early nineteenth century under the continued family leadership of Henry and especially Samuel Tuke (son and grandson respectively of William Tuke) spawned a number of imitators. For instance, in the East Riding alone from 1814 until 1898, of the fourteen private asylums that opened and closed, seven had the name "Retreat" in their title."

The Friends who met at Devonshire House in London on 1 June 1839, the day after Yearly Meeting, to discuss the "propriety of forming an Institution for the Insane, in the South of England" were conscious of a kinship with York Retreat that was more than semantic, for those present included men who had contributed to York Retreat and who were friendly with that institution's leaders. The main

*Charles L. Cherry, M.A., Ph.D., Assistant to the Academic Vice-President, Villanova University, Villanova, Pa. 19085, U.S.A.

1 The brief history of "The Southern Retreat" is recorded in two vellum books from Manuscript Box H-13 in the Library of the Religious Society of Friends, London. One, a small lined ledger book, lists the names and amounts of the various investors in this project. On its cover are the names of the three trustees of these funds: John Sanderson, John Pryor, and Joseph Jackson Lister. The second, an unlined journal, contains a copy of the prospectus and the rough minutes of the fifteen recorded meetings held from 1 June 1839 to around May 1841. I wish to thank Malcolm Thomas of the library staff for bringing these materials to my attention.

${ }^{2}$ See J. A. R. Bickford and M. E. Bickford, The private lunatic asylums of the East Riding, Beverley, East Yorkshire Local History Society, 1976. The name "Retreat" was suggested by Mary Maria, Henry Tuke's lively, intelligent wife. Hartford Retreat, now the Institute of Living, continued the Quaker semantic tradition in the United States. 


\section{The Southern Retreat, Thomas Hodgkin, and Achille-Louis Foville}

force and paramount figure at this meeting was Thomas Hodgkin (1798-1866). A man of broad interests, ranging from his original investigations of lymph glands while a pathologist at Guy's Hospital to his intense anti-slavery efforts, Hodgkin was a birthright Quaker and a member of Westminster Meeting at the time of his attempt to found the Southern Retreat. He had also been a close friend of Samuel Tuke for several years. ${ }^{3}$

Out of this 1 June meeting came a special committee consisting of Hodgkin, Dr. Ball, John Sanderson, Joseph Jackson Lister, Samuel Gurney jr., and Thomas Bevan. They worked with others to compose a prospectus of the project. At a meeting held on $15 \mathrm{July}$, those present supported this document, which was henceforth dated 17 July 1839 and distributed to potential supporters under the title "Proposals for the establishment of a lunatic asylum under the care of Friends, to be called the Southern Retreat."4

The prospectus begins by paying respectful tribute to the work of York Retreat, but repeats a concern first expressed by Friends when William Tuke was seeking support for his venture - namely, the "expensive, painful, and fatiguing travelling" which Friends in Southern England must undergo to reach York. The Southern Retreat would hope to imitate the kind of care for which York Retreat was famous and would continue the practice of receiving wealthy patients, Friends or otherwise, ${ }^{5}$ at increased terms by way of subsidizing the reception of poorer patients:

The feasibility of this project is almost demonstrated by the fact that the Managers of the Retreat at York, have within a comparatively short time contemplated the establishment of such an Institution by the employment of their own accumulated funds. Local changes which have induced the Directors to abandon the plan, have not, however, materially diminished the expediency of the measure, which has been approved by competent judges in the Medical Profession, and is called for by the fact that it has repeatedly been found necessary to send Insane Friends to Asylums in no way connected with the Society.

Should enough financial support be given, the prospectus continues, Dr. Foville would be hired as medical director, with high hopes for his success: "The advantages of treatment under his direction would doubtless not be confined to the inmates of the Institution, but a most important reform in the medical and physical treatment of the Insane might reasonably be expected to spread from this Institution to most of the considerable Lunatic Asylums in this country." Of more importance, Foville's

${ }^{3}$ R[ichard] Hunter, 'Thomas Hodgkin, Samuel Tuke, and John Conolly', Guy's Hosp. Rep., 1966, 115: 263-267. Hunter points out that Hodgkin was consulted by Tuke on his daughter Sarah's illness, and that Hodgkin introduced Tuke to Conolly, at Edinburgh in May 1821 while Tuke was in the area visiting New Lanark. William Allen, a Quaker and lecturer on chemistry at Guy's Hospital, was a part-owner of the mills.

- See the appendix for a complete copy of the prospectus.

- A tabulated return of persons admitted into the retreat 1796-1911 indicates that not until 1820 was a person admitted who was unconnected with the Society of Friends, though doubts were expressed about the connexion of a few. The number of unconnected members increased after 1820, but not dramatically. Of the twenty-one patients admitted in 1830 only three were unconnected; in 1840 we find six of twenty-three unconnected; in 1850, one of seventeen; in 1860, seven of fifteen; in 1870, eight of nineteen; in 1880, twenty-one of thirty-six; in 1890, nineteen of twenty-six. By 1900 only four of the forty patients admitted were connected. Retreat archives and Tuke papers are housed at the University of York's Borthwick Institute of Historical Research. 


\section{Charles L. Cherry}

presence would signify a radical departure from the heritage of York Retreat: "As the Northern Retreat has had the merit of contributing materially to improve the moral management and personal condition of British Lunatics, so its Southern counterpart might be equally happy in effecting a similar amelioration in the very important but too much neglected branch, to which belongs the medical treatment of mental and cerebral disease."

The prospectus then makes an appeal to raise $£ 20,000$ through the sale of 400 shares of $£ 50$ each with no individual holding more than twenty shares. The net proceeds of the institution would be divided among shareholders, with a maximum individual gain of seven and one-half per cent per year on money invested, any surplus going to "the improvement of the establishment". Also, a guarantee-list would enable those who did not wish to buy shares to support the institution by guaranteeing with the shareholders any moneys lost during the first seven years of operation.

I have already named Thomas Hodgkin as the moving force behind the Southern Retreat. Several facts support this idea, the most important being his relationship to Foville. Achille-Louis Foville (1799-1878) was born at Andelys, studied medicine at the University of Paris, and interned under Esquirol at the Salpêtrière. ${ }^{6}$ His 1824 medical thesis is dedicated to "mes maitres Esquirol, Ferrus, Pinel et Rostan," and is entitled "Observations cliniques propres à éclairer certaines questions relatives à l'aliénation mentale". ${ }^{7}$ In this work he takes issue with those who feel that madness is incurable and who "attribuent toujours sa terminaison aux bienfaits de la nature, et jamais aux resources de l'art". Citing the success of the medical approach in a variety of cases, such as the cure of hysterical mania through the use of blisters on the neck and cold water, he concludes that "la folie est curable". Following graduation, and on Esquirol's recommendation, Foville was appointed medical superintendent in 1825 of the Saint-You Asylum at Rouen, which had just opened, and he later became a professor of physiology at the Rouen medical school. When Esquirol died in 1840, Foville was appointed the chief medical officer at Charenton, a post which he lost in the political revolution of 1848. His major work was Traité complet de l'anatomie, de la physiologie et de la pathologie du système nerveux cérébro-spinal (Paris, 1844), the fruit of his many years of cerebral researches. Thomas Hodgkin is acknowledged in the preface to this work: "Mon excellent ami le docteur Hodgkin de Londres a trouvé moyen de me seconder malgré la distance qui nous sépare."

Their friendship obviously antedates this work, going back perhaps as far as the period of Hodgkin's Paris studies at the Necker Hospital in $1822 .{ }^{8}$ What would have

\footnotetext{
- A slim outline of facts about Foville may be found in an obituary article in Gaz. hebd. Méd. Chir., 1878, 15: 499-500. This article was adapted for publication in Med. Times Gaz., 1878, 2: 232. His son Achille-Louis Foville fils (d. 1887), was editor-director of Annls méd.-chir. and at various times medical director or superintendent of asylums at Dóle, Châlons-sur-Marne, and Quatres Mares. See Am. J. Insan., 1888, 44: 573.

7 Collection des theses soutenues à la Faculté de Médecine de Paris an 1824, tome quatrième, thèse 109 à 146, Paris, Sorbonne, 1824. Foville's thesis is No. 138.

${ }^{8}$ E. H. Kass notes that Hodgkin helped to introduce the use of the stethoscope to England after observing Laënnec at this time. See 'Thomas Hodgkin, physican and social scientist', Guy's Hosp. Rep., 1966, 115: 272.
} 


\section{The Southern Retreat, Thomas Hodgkin, and Achille-Louis Foville}

drawn them together, besides Hodgkin's fluent command of the French language, was a mutual interest in pathology. In an $1827 \mathrm{speech}^{9}$ on medical education delivered before the Physical Society of Guy's Hospital, Hodgkin paid tribute to French pathologists and may well have had Foville in mind. The Hodgkin papers ${ }^{10}$ reveal more certain evidence of their relationship. A letter to Hodgkin from William Stroud dated 6 December 1830 speaks of Foville's stay in England. Stroud asks for an introduction so that he might see Foville's "preparations of the brain". And in Hodgkin's diary entries for summer 1838 there are a number of references to dinner and travel with Foville and William Frédéric Edwards, whose work On the influence of physical agents on life (1832; trans. 1838) had been translated from the French by Hodgkin.

One can reasonably speculate that despite the lack of his own writings on the subject of mental illness, Hodgkin had his appetite whetted for the scientific aspects of the study by his close interaction with the experienced Foville, and by his general scientific curiosity. Though he wrote a biographical sketch of James Cowles Prichard, the man who coined the phrase "moral insanity", Hodgkin had a greater interest in "chemical physiology" (Letters, 1 May 1839) and the physical effects on the brain as seen in pathological investigation. Also, while his many humanitarian venturesranging from concern over poor sanitation, chimney sweeps, drunkenness, and bad housing to his anti-slavery efforts and presidency of the Aborigines Protection Society -consumed much of his time, Hodgkin was pre-eminently a scientist, one who concurred with his colleague Sir William Withey Gull's remark that "The road to medical knowledge is through the Hunterian [pathological] museum, and not through an apothecary's shop."11 Hodgkin had little sympathy for those who administered remedies without knowledge of the disease. His humanitarian and scientific impulses converged admirably in the plan to establish an asylum whose medical emphasis would complement the moral direction of York Retreat. Hodgkin probably felt that a clearer, more comprehensive medical approach to mental illness, combined no doubt with detailed pathological examinations, would advance both the store of medical knowledge and the reputation of the Southern Retreat, just as over forty years earlier the "Northern Retreat" began making its impact through a moral regimen of religion, sound diet, and useful labour. This is the reason for the sense of optimism conveyed by the prospectus. And for Hodgkin, who could better head such an institution than a close friend, an experienced alienist, and a noted pathologist?

We should keep in mind, however, that the dichotomy suggested by medical-moral approach was not a radical one. Like the mind-body problem, it was more a matter of emphasis. The Southern Retreat would not neglect the moral aspects of care any

\footnotetext{
- An essay on medical education, read before the Physical Society of Guy's Hospital, at the first meeting of the session 1827-8, London, William Phillips, 1828, p. 20.

${ }_{10}$ The bulk of Hodgkin's papers, many unpublished, are still held by the family. The author is grateful to Mr. Thomas Hodgkin for permission to quote from the microfilm copy of these papers available at the Library of the Religious Society of Friends, London.

11 Samuel Wilks and G. T. Bettany, A biographical history of Guy's Hospital, London, Ward, Lock, Bowden, 1892, p. 264. Under a provision of Guy's will the Hospital was to care for up to twenty incurable lunatics. Hodgkin's probable contact with these patients presumably increased his interest in mental illness.
} 


\section{Charles L. Cherry}

more than York Retreat neglected the medical. Bleedings, blisters, and evacuants were used at York Retreat, but without success, so as time progressed, its leaders felt less confident of the medical approach, excepting perhaps the warm bath. Yet Samuel Tuke often spoke of the "inexplicable sympathy"12 between body and mind. In a diary note of 22 January 1817, he speaks of nightmares being the product of indigestion and suggests bodily disorders as the cause of some cases of insanity. Reason, he says, is: "liable to be eclipsed by the derangement of those organs which we in degree understand, and, [is] perhaps, infinitely more subject to the vicissitudes and diseases of those finer parts of our bodily frame, of which we know no more, than that they baffle our greatest skill to dissect or unravel. Here and here alone is the true source of cheerfulness and confidence-that not one hair of our heads shall fall to the ground without our heavenly Father's knowledge."13

Still, moral treatment remained the primary concern of York Retreat. This philosophy of care challenged a profession based on medical care of the insane and the profitable administration of homemade, expensive nostrums. As Andrew Scull notes, ${ }^{14}$ doctors were threatened in the period of York Retreat's success with admitting that they could not demonstrate the efficacy of medical treatment; as a result, sympathetic laymen like William Tuke were as capable of heading asylums as medical men. But gradually the medical profession assimilated moral treatment into its plan of treatment and reasserted its primacy and authority to treat mental illness as a medical problem. The Madhouse Act of 1828 reinforced this change. Among other provisions, it required that all patients receive visits by doctors and that all asylums with more than one hundred patients be run by medical directors.

These changes no doubt influenced Hodgkin's conception of his asylum. A religious man, but also a careful scientist, he wanted more certainty and was more confident of medical solutions. The Southern Retreat would place its emphasis on close bedside observation of physical symptoms combined with cadaveric examinations. The man who confidently proclaimed from a medical viewpoint that "la folie est curable" would head the Southern Retreat. Thus on 12 March 1839 Hodgkin wrote to Foville on a matter he had no doubt broached on earlier visits to Paris: "I have spoken to my friends on the subject of the lunatic asylum which $I$ have proposed to have established and which I have long thought was really wanted but which could be more than doubly important if it could have the advantage of thy medical direction." Hodgkin admits that a particular friend ${ }^{15}$ is not sanguine about Hodgkin prevailing

\footnotetext{
${ }^{12}$ Samuel Tuke, Description of the Retreat: an institution near York for insane persons of the Society of Friends containing an account of its origins and progress, the modes of treatment, and a statement of cases, London, 1813, p. 116.

${ }_{18}$ Memoirs of Samuel Tuke: with notices of some of his ancestors and descendants, vol. 1, p. 291.

14 See 'From madness to mental illness: medical men as moral entrepreneurs', Arch. europ. Sociol., 1975, 16: 218-251; and 'Mad-doctors and magistrates: English psychiatry's struggle for professional autonomy in the nineteenth century', ibid., 1976, 17: 279-305.

${ }_{15}$ See Katharine Fry and Rachel Elizabeth Cresswell (editors), Memoirs of the life of Elizabeth Fry with extracts from her journals and letters, 2nd ed. rev. and enl., London, John Hatchard, 1847, vol. 2, pp. 261-333. The friend referred to is Josiah Forster, a member of the Anti-Slavery Society, who was travelling in Paris at this time with Elizabeth Fry, her husband, and daughter on one of Mrs. Fry's many excursions to jail and hospitals. Hodgkin had written a letter of introduction on their behalf to Foville. Other letters suggest that Foville apparently had a part in the French publication of the works of Elizabeth Fry's brother, Joseph John Gurney.
} 


\section{The Southern Retreat, Thomas Hodgkin, and Achille-Louis Foville}

on Foville, but that the "subject is one which has [not] sufficiently come under his consideration for him to be aware of its importance." Friends' Yearly Meeting, Hodgkin continues, will occur in about two months, and that will be the "time when its practicability may be decided on and steps for its commencement may be taken...." Hodgkin then concludes with a wish that Foville's "cerebral researches" are going well.

As mentioned, it did not take the committee much time after the 1 June 1839 meeting to do its work. Meetings subsequent to the issuing of the prospectus concentrated on establishing a constitution for the asylum and selecting a housing site. On 18 May 1840 Rickman Godlee, Lister's son-in-law and secretary of the Southern Retreat Committee, asked all subscribers to remit $£ 10$ per share on shares subscribed for so that suitable grounds might be leased. By the deadline of 1 June $1840 £ 1,620$ had been collected and by 11 July $£ 2,450$ was in hand; since this represented but twenty per cent of the total amount committed by the subscribers, this meant that $£ 12,250$ had already been subscribed for the Southern Retreat. Money was no problem; other difficulties arose to foil the entire venture.

The ostensible difficulty was the failure to secure a suitable property. Long negotiations were held with a Dr. Jersey of Wyke House near Brentford, who initially was interested in leasing the committee a property for twenty-one years. Negotiations fell through, however, and subscribers were urged in a 13 July 1840 notice to recommend other possible sites. The Minute Book records an energetic pursuit and examination of possible locations. Areas in and around London were checked-Leyton, Chelsea, Hampstead, Southgate, Hammersmith—but to no avail. Finally a letter dated 17 May 1841 went out to all subscribers indicating that despite extensive inquiries and inspection of various houses, the committee had not been successful in acquiring a property they could recommend as suitable.

The letter mentions another difficulty: "The Committee have recently learned that Dr. Foville, whose services it was proposed to obtain for the medical direction of the Institution, and who, for a long time, held himself at liberty for that purpose, has now, in consequence of an opportunity occurring which did not admit of delay, entered into an engagement with an establishment in France." The post alluded to is that of the medical directorship at Charenton. Foville's decision sealed the fate of the proposed Southern Retreat. In consideration of the failure to find a proper home for the asylum and to secure the services of its chosen medical director, the committee decided to return all money to subscribers, less minor expenses, ${ }^{16}$ and the entire venture thus came to an end, with its records forgotten. The initial enthusiasm with which the ideas were greeted failed to translate into a visible institution. And what of Hodgkin? I found no record of his personal reaction to defeat. However, his correspondence for the 1839-41 period reveals a heavy absorption in the slavery issue and especially the Aborgines Protection Society, which, with Sir Thomas Fowell Buxton, he had founded in 1838. These duties, as the letters and journals indicate, included a world-wide correspondence with supporters, the writing of declarations, and numerous personal interviews with the Colonial Secretary and

${ }^{16}$ Hodgkin, for example, having pledged five shares and paid $£ 50$ on account, received back $£ 49$ 13s. 2d.- thus suffering a slight financial loss. 


\title{
Charles L. Cherry
}

other officials. No doubt this involvement distracted his attention, causing Rickman Godlee to assume a greater part of the logistic chores, including secretarial duties and recording the minutes of the meetings.

One other block to the successful establishment of Southern Retreat is worth mentioning, not only to clarify the difficulties besetting Hodgkin and his committee, but also to draw us back full circle to the establishment of York Retreat. For some evidence exists to show that Hodgkin, like William Tuke, faced problems emanating from within the Society of Friends itself. Tuke met with much indifference and some suspicion of his efforts. Some Quakers questioned the expense involved in building York Retreat, its distant location from London, and the essential need of a separate Quaker asylum - the kinds of doubts that ultimately caused Tuke to lament that "All men seem to desert me in matters essential". ${ }^{17}$ Hodgkin too had his problems with fellow-Quakers, the most important one being Samuel Tuke.

Samuel Tuke attended Hodgkin's 1 June 1839 meeting at Devonshire House. But, since he was Clerk of Yearly Meeting and would be in London anyway, and since he had been connected with York Retreat most directly as its Treasurer and as the author of the influential Description of the Retreat (1813), it would have been very odd for him not to have been invited and for him not to have accepted the invitation, the more so since he and Hodgkin were friends of long standing. Yet because of Tuke's close attachment to York Retreat and its therapy of moral management, it is equally understandable that he might have been lukewarm or even hostile to the idea of a rival Quaker asylum with a different philosophy of care. An important letter of 21 August 1839 from Hodgkin to Tuke touches on this tension:

\begin{abstract}
Although I am aware that thou hast felt some doubt as to the present necessity for a lunatic asylum in the South of England in some respects resembling your Retreat and destined for the reception of members of the Society of Friends yet $I$ believe that there are few if any persons who will feel more interested in the progress and results of the Institution should it be formed than thyself. That it will be established is now I think scarcely to be doubted as names are given in for shares to the amount of more than $\$ 10,000$. In its progress I think we may be excused if we occasionally apply to thee for advice and assistance.
\end{abstract}

After this diplomatic opening, Hodgkin immediately moves to the question of Foville. He says that the "loss will be incalculable" if Foville cannot head the institution. He elaborates on the need for Foville:

After having visited many asylums and seen several medical men engaged in the treatment of the insane and of course being somewhat acquainted with the writings of others I certainly know of no one to be compared to the Dr. He is both theoretically and practically very far before his master Esquirol and yet he is looked up to both on the Continent and in this country. I cannot help feeling that if we appoint Dr. F. we rather than the Dr. will be the obliged party. It is therefore rather trying to find that it is said that ours is a job got up by the Drs. The reverse is really the case .... And as respecting myself though my means are very limited I intended to subscribe rather than to invest had there been subscribers. As regards Dr. Foville I ought to say that he is leaving very serious prospects in consenting to join us. The state of Esquirol's health is such that the several lucrative appointments which he holds must soon be vacant

17 For an indication of William Tuke's problems, see the 1 April 1793 letter from Samuel Birchall and 16 March 1793 letter from William Alexander among the Tuke Papers at the University of York's Borthwick Institute of Historical Research. 


\section{The Southern Retreat, Thomas Hodgkin, and Achille-Louis Foville}

and to some of these there is the strongest reason to believe that Dr. Foville might be appointed. His well earned reputation as a cerebral pathologist, as a writer on Insanity and kindred subjects and his proved abilities as exhibited at the Hospice de St. You at Rouen would justly entitle him to any office of the kind which he might seek. ...

Hodgkin then further details Foville's virtues and experience, remarking how his attendance on the king of France for a year should place him in a favourable position for future appointments. Why then does Foville wish to come to England? "He is however a highly serious man, by no means avaritious [sic] and very anxious correctly to bring up his two children as well as to enjoy quiet for the publication of the materials which [he] has been long collecting. It is this disposition which makes him prefer the prospect of being with us to the change of having the best post in a Parisian Institution." The defensive tone of these remarks suggests that the Southern Retreat proposal had come under attack from other Friends or perhaps from Tuke himself. In any case, Hodgkin becomes aggressive toward the end of the letter. He says that some are suspicious of Foville because he is a "foreigner". He concludes by asking Tuke to write a letter supporting Foville as medical superintendent. He refers to Dr. Prichard and Caleb Williams, the surgeon at York Retreat, as individuals familiar with the quality of Foville's work. 18

I have found no record of Tuke's response, if indeed there was one. No doubt if one existed, D. Hack Tuke, the probable editor of The memoirs of Samuel Tuke, would have included it in that work, but he never mentions in this or his many important works such a letter or the proposed Southern Retreat itself. In fact, without the Friends Library materials coming to light, we would have no knowledge of the attempt to found the Southern Retreat. Since the scheme never came to fruition, we can only speculate as to the kind of research that might have been conducted, and as to its ultimate worth and influence. Perhaps the Southern Retreat might have caused its own kind of revolution in the history of psychiatric care and treatment. As matters stand, however, we can only look to these documents as added testimony to the Quaker tradition of good works and in particular as another chapter in the history of Thomas Hodgkin's humanitarianism.

\section{SUMMARY}

Led by Thomas Hodgkin, a group of prominent London Quakers, including Joseph Jackson Lister, Samuel Gurney jr., and Thomas Bevan, attempted in 1839 to establish "The Southern Retreat" as a counterpart to the Tuke-inspired York Retreat. Funded by subscriptions, it was to be located near London and run by Achille-Louis Foville, an experienced alienist and pathologist, who was also a longtime friend of Thomas Hodgkin.

\footnotetext{
${ }^{18}$ Though his name does not come up, Hodgkin might also have mentioned John Kitching. Kitching, who pledged five shares to the Southern Retreat, was at the time translating Maximilian Jacobi's On the construction and management of hospitals for the insane, with a particular notice of the institution at Siegburg, 1834, trans. 1841, for which Tuke supplied an introduction. Kitching eventually became medical superintendent of York Retreat from 1849 to 1874 . He is mentioned in the Devonshire House minutes of 9 July 1840 as having applied for the post of superintendent of the Southern Retreat. He requested $£ 200$ per annum, plus a home and board.
} 


\title{
Charles L. Cherry
}

Documents recently discovered at the Library of the Religious Society of Friends in London reveal that the new asylum was to be medically oriented in its approach to mental illness, in contrast to the moral emphasis of York Retreat. That is, while not neglecting nature and human kindness, it would presumably affirm that these are not necessarily the best ways to treat mental illness. It would restore a more traditional medical approach with greater use of medicines, research, and cadaveric examination.

By July 1840 , following a general appeal, more than $£ 12,000$ had been subscribed to establish the institution, but a number of problems arose to prevent the project from reaching fruition. The most obvious one was the failure to locate an agreeable site for the building. Another was the loss of Foville. Because of delays and possible resentment over his being a foreigner, he decided to become medical director at Charenton in 1840, succeeding Esquirol.

Another possible reason for the abandonment of the project was the suspicion, even hostility, of some Friends regarding the venture. We know that Hodgkin wrote to Samuel Tuke to defend the choice of a "foreigner" to head the asylum and to solicit Tuke's aid in the venture. Probably, if Tuke was not hostile, he was less than enthusiastic about a venture whose philosophy of treatment ran counter to his own, but no records are available to confirm this suspicion. In any case, the plan to establish "The Southern Retreat" was abandoned. We are left only with speculations about the kind of impact it might have had on the history of psychiatry. The effort remains as added testimony to the Quaker tradition of good works and as a footnote to the history of Thomas Hodgkin's humanitarianism.

\author{
APPENDIX I \\ PROPOSALS \\ FOR THE ESTABLISHMENT OF A \\ LUNATIC ASYLUM UNDER THE CARE OF FRIENDS, \\ TO BE CALLED
}

THE SOUTHERN RETREAT.

To those who are acquainted with the merits of the Lunatic Asylum, under the care of the Society of Friends near York, called the Retreat, it is presumed that little need be said, either to set forth the benefits which that Institution has conferred, and still continues to confer, or to produce conviction as to the further benefits which might yet be obtained, by the establishment of a similar Institution within a moderate distance from London.

Although there are already numerous Lunatic Asylums in the neighbourhood of the Metropolis, which enjoy a well merited reputation, in consequence of the general care and management of their Directors, yet it is certain that a strong preference exists in the minds of Friends, in favour of sending such members of the Society as may be affected with mental alienation to York, where their religious peculiarities are not likely to subject them to any annoyance or inconvenience, rather than to allow them to be exposed to some trials, which in their peculiar state, would not be unlikely to occasion an increase of moral and physical suffering. In the case of persons in low circumstances, these difficulties would probably be felt in the greatest degree-but those in affluence cannot be always exempt from them.

An Institution such as is here suggested, would therefore not merely be a saving of much expensive, painful, and fatiguing travelling, but would enable many, to whom the advantages of the Retreat are necessarily denied, to enjoy precisely similar advantages, with, very probably, the addition of some others which will be presently noticed. 


\section{The Southern Retreat, Thomas Hodgkin, and Achille-Louis Foville}

It has been the practice at the Retreat not merely to receive on higher terms Patients from the wealthier class of Friends, but also Patients belonging to other Religious Professions, whose relatives repose confidence in the management of the Institution, and who are willing to pay on such liberal terms as contribute greatly to benefit the funds of the establishment. A similar course might doubtless be adopted by the Managers of a Lunatic Asylum under the care of the Society of Friends, situated in the vicinity of London. The advantage would be reciprocal, for the higher class of Patients, whilst aiding the funds of the Establishment, might be so distinct from the poorer class as to be subject to no degree of annoyance from them, but they would derive great benefit from the superior medical and other treatment which the Superintendent and Medical Director would, as experienced practical men, be ever ready to suggest.

The feasibility of this project is almost demonstrated by the fact that the Managers of the Retreat at York, have within a comparatively short time contemplated the establishment of such an Institution by the employment of their own accumulated funds. Local changes which have induced the Directors to abandon the plan, have not, however, materially diminished the expediency of the measure, which has been approved by competent judges in the Medical Profession, and is called for by the fact that it has repeatedly been found necessary to send Insane Friends to Asylums in no way connected with the Society.

Should the foregoing proposal obtain the concurrence of a sufficient number of supporters, the present time would be peculiarly favourable to its adoption, since there is an opportunity of obtaining for the medical direction of the proposed institution, the services of DR. Foville, whose intimate theoretical and practical acquaintance with this branch of medicine, justly entitles him to the very highest place in this department.

The advantages of treatment under his direction would doubtless not be confined to the inmates of the Institution, but a most important reform in the medical and physical treatment of the Insane might reasonably be expected to spread from this Institution to most of the considerable Lunatic Asylums in this country.

As the Northern Retreat has had the merit of contributing materially to improve the moral management and personal condition of British Lunatics, so its Southern counterpart might be equally happy in effecting a similar amelioration in the very important but too much neglected branch, to which belongs the medical treatment of mental and cerebral disease.

On the first of the sixth month, being the day following the Yearly Meeting, several Friends from different parts of the Country, met at Devonshire House, and took into consideration the preceding proposal, and a Committee was formed, consisting of DR. BALL,- JOHN SANDERSON,Joseph Jackson Lister,-SAmuel GuRney, Jun.-Thomas Bevan, and DR. Hodgkin, who were requested to digest and prepare a plan for further consideration.

After repeated meetings of the Committee, assisted by many other friends, the following plan has been agreed to, as the basis of the proposed establishment.

1.-That an institution be formed, to be under the care of a Committee, consisting of members of the society of Friends, and that it be called "THE SOUTHERN RETREAT".

2.-That capital to the amount of $£ 20,000$ be raised, in 400 Shares of $£ 50$ each, and that the shares be transferable, but that no individual be allowed to hold more than 20 shares.

3.-That an estimate of the property and liabilities of the institution be taken annually, and that the net proceeds be divided among the Shareholders, in proportion to the amount of capital subscribed; but that they be not entitled to receive more than $7 \frac{1}{2}$ per cent. per annum, from the commencement of the institution, and that the surplus, if any, be appropriated to the improvement of the establishment.

4.-That a Guarantee-list be opened, in order to afford to individuals who may not be desirous of taking shares, an opportunity of supporting the institution, by undertaking, in case a loss of capital should be incurred during the first seven years, to participate with the Shareholders therein, in such proportion as the sums for which they may subscribe, the Guarantee-list bear to the whole capital advanced.

5.-That the managing Committee be appointed annually, at a general meeting of the Shareholders and Guarantees.

Members of the Society of Friends, and other persons who are desirous of aiding in the formation of the proposed institution, either as Shareholders or Guarantees, are requested to transmit their names, with the number of shares they are willing to hold, or the sums for which they are willing to become Guarantees, previously to the meeting to be held as under, to

JOHN SANDERSON, Old Jewry, EDWARD HARRIS, New Broad Street, Dr. HODGKIN, 9, Brook Street, Grosvenor Square, 


\section{Charles L. Cherry}

THOMAS BEVAN, 20, Finsbury Circus,

WILLIAM MANLEY, 86, Houndsditch; or

THOMAS FOWLER, (DREWETT \& FOWLER,) Princes Street, Bank.

THE NEXT GENERAL MEETING

Will be held at FriEnds' MEETING House, HoundsDITCH, on the twenty-ninth of the present month, AT THREE O'CLOCK in the afternoon, for the purpose of adopting measures for carrying the plan into effect; on which occasion, it is particularly desirable that the Friends to the undertaking should be generally present.

LONDON, 17th of 7th Month, 1839. 